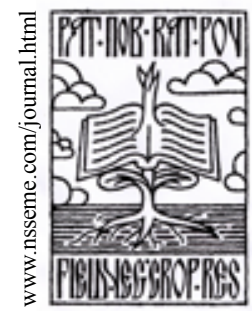

\title{
Effect of Microwave Heating on Content of Cyanogenic Glycosides in Linseed
}

\author{
Dušica Ivanov • Bojana Kokić • Tea Brlek • Radmilo Čolović • \\ Đuro Vukmirović • Jovanka Lević • Slavica Sredanović
}

\author{
received: 4 November 2011, accepted: 12 December 2011 \\ (C) 2012 IFVC \\ doi: $10.5937 /$ ratpov $49-1173$
}

\begin{abstract}
Summary: Linseed is a good source of linoleic (LA, 18:2, n-6) and especially $\alpha$-linolenic acid (ALA, 18:3, $n-3), \omega 6$ and $\omega-3$ polyunsaturated fatty acids (PUFA), which are essential because mammals, and therefore humans, cannot endogenously synthesize them and must adopt them exogenously from dietary sources. In spite of its high nutritive value, linseed has not been effectively exploited in animal feeding, due to the fact that it contains antinutritive components, which are cyanogenic glycosides (CG) and antivitamin B6 (linatine). CGs are a major limitation in application of linseed and its meal in animal nutrition. The objective of the study was to investigate effect of microwave heat treatment on the content of hydrogen cyanide, and consequently cyanogenic glycosides in linseed. Operating frequency of microwave oven was $2450 \mathrm{mHz}$, and working power was $240 \mathrm{~W}, 400 \mathrm{~W}, 560 \mathrm{~W}$ and $800 \mathrm{~W}$. Samples were treated for 0, 3, 6 and 10 minutes for every working power. When microwave power of $560 \mathrm{~W}$ and $800 \mathrm{~W}$ was used for $6 \mathrm{~min}$ and longer, linseed samples were burned and damaged, therefore these treatments should not be used. Minimal time of heating with microwave power of $400 \mathrm{~W}$, which would provide reduction of HCN content under allowed limits $(250 \mathrm{mg} / \mathrm{kg}$ of linseed), was determined graphically using three-dimensional contour plot graph and it was $290 \mathrm{~s}$ ( 4 minutes and $50 \mathrm{~s}$ ). This regime is recommended for treating linseed before usage as a feed compound.
\end{abstract}

Keywords: cyanogenic glycosides, hydrogen cyanide, linseed, microwave heating

\section{Introduction}

Linseed (Linum usitatissimum) is an annual or biannual plant, one of the most useful crops, that has been cultivated as a commercial plant in over thirty countries all over the world (Karlović \& Andrić 1996, Gabiana 2005). It yields seeds that mature 30-60 days after flowering (Matheson 1976), and which are rich source of both edible and non-edible oils. Containing about $40 \%$ of oil, the seeds have long been used in animal diet. Recently there has been a growing interest in linseed oil due to the high concentration of linoleic (LA, 18:2, n-6) and especially $\alpha$-linolenic acid (ALA, 18:3, n-3) (Eukaszewicz et al., 2004). Furthermore, linseed is the richest oilseed source of ALA (Juárez et al. 2010). These fatty acids are representative of $\omega 6$ and $\omega-3$ polyunsaturated fatty acids (PUFA), which are essential because mammals, and therefore humans, cannot

D. Ivanov • B. Kokić • T. Brlek* • R. Čolović • Đ. Vukmirović • J. Lević - S. Sredanović

University of Novi Sad, Institute of Food Technology, Bul. cara Lazara

1,21000 Novi Sad, Serbia

e-mail: tea.brlek@fins.uns.ac.rs endogenously synthesize them and must adopt them exogenously from dietary sources (Beare Rogers et al. 2001). One way to increase content of $\omega-6$ and $\omega-3$ PUFAs and improve their ratio in human diet is by modifying fatty acid composition in meat, which is a natural supplier of fatty acids. This is usually done by feeding animals with meals containing seeds rich in $\omega$ PUFAs, such as linseed (Okanović et al. 2010).

In spite of its high nutritive value, linseed has not been effectively exploited, due to the fact that it contains antinutritive components, which are cyanogenic glycosides (CG) and antivitamin B6 (linatine). Several sources reported that negative effect of antivitamin $\mathrm{B} 6$ could be eliminated by adding vitamin $\mathrm{B} 6$ in the diet (Madhusudhan \& Singh 1985, Klosterman 1974).CG are chemically defined as glycosides of the $\alpha$-hydroxynitriles. They are amino acid-derived secondary metabolites

ZAcknowledgement: The experimental work presented in this paper is a part of an integrated and interdisciplinary research project III 46012 titled "Investigation of contemporary biotechnological processes in feed production aimed at increasing food competitiveness, quality and safety" funded by the Ministry of Education and Science of the Republic of Serbia. 
produced by plants, whose biosynthetic precursors are different L-amino acids (Vetter 2000). CGs in linseed are linamarin, $\beta$-gentiobiose acetone cyanohydrins (linustatin), and $\beta$-gentiobiose methylethyl ketone cyanohydrins (neolinustatin), presented in Fig. 1.
There are several conventional methods for determination of content of cyanogenic glycosides in food or plant material. Ganjewala et al. (2010) give an overview of qualitative and quantitative methods for detection of CG in plant material such as gas chromatographic analysis (Bacala

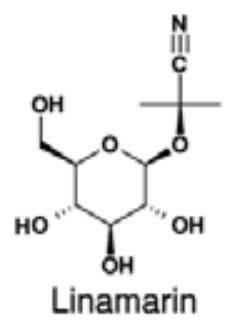

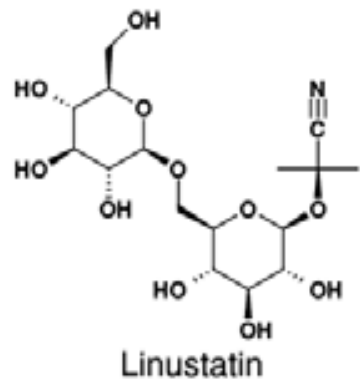

Linustatin

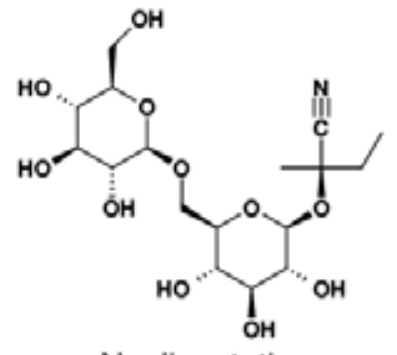

Neolinustatin

Fig. 1. Chemical composition of cyanogenic glycosides in linseed

Slika 1. Hemijska struktura cijanogenih glikozida u lanenom semenu

CG present a major limitation in application of linseed and its meal in animal nutrition. The reason for toxicity of CG lies in releasing of hydrogen cyanide $(\mathrm{HCN})$ due to the action of a $\beta$-glucosidase enzyme (oxynitrilase), thus their level in food or feed is expressed trough content of HCN (mg) per $\mathrm{kg}$ of examined material. According to literature, the following animal species tolerate (mg HCN equivalents/ $\mathrm{kg}$ body weight per day): pigs $(2.9 \mathrm{mg} / \mathrm{kg}$ per day), poultry $(2.8 \mathrm{mg} / \mathrm{kg}$ per day), ruminants (on the basis of goat studies) $(0.25 \mathrm{mg} / \mathrm{kg}$ per day), and horses $(0.4 \mathrm{mg} / \mathrm{kg}$ per day). There are no studies investigating fish and fish feed that would allow the determination of a tolerated level in feedstuffs; however, a total cyanide concentration in the water of $0.2 \mu \mathrm{mol} / \mathrm{l}$ is considered to give not observable adverse effects (EFSA 2006).

Serbian regulation on quality of feedstuff 2010 , act 99 requires maximum content of $250 \mathrm{mg}$ of $\mathrm{HCN} / \mathrm{kg}$ of linseed and $350 \mathrm{mg} \mathrm{HCN} / \mathrm{kg}$ of linseed meal and cake (Republika Srbija 2010). EU Regulation (EC) No 1334/2008, Annex III of Directive $88 / 388$ on flavourings allows the following maximum permitted levels of $\mathrm{HCN}$ in foodstuffs and beverages to which flavourings or other food ingredients with flavouring properties have been added: $1 \mathrm{mg} / \mathrm{kg}$ in foodstuffs, $1 \mathrm{mg} /$ $\mathrm{kg}$ in beverages, with the exception of $50 \mathrm{mg} / \mathrm{kg}$ in nougat, marzipan or its substitutes or similar products, $35 \mathrm{mg} / \mathrm{kg}$ in alcoholic beverages and 5 $\mathrm{mg} / \mathrm{kg}$ in canned stone fruit. There is no data for limitation of $\mathrm{HCN}$ content in linseed for feeding animals in EU (EEC 2008).
\& Barthet 2007), liquid chromatography (LC) combined with tandem mass spectrometry (LC-MS/MS) (Franks et al. 2005), alkaline or acid titration method (AOAC 2000), direct determination of cyanides by potentiometric biosensors (Keusgen et al. 2004), picrate paper and picrate paper kits (AOAC 2000, Hidayat et al. 2000), densitometric method (Brimer \& Molgaard 1986), immunoassay using polyclonal antibodies (Cho et al. 2006), etc. Different heat treatments, such as autoclaving, pelleting, extrusion, or microwave roasting are usually used for reduction of content of cyanogenic glycosides (Feng et al. 2003, Wu et al. 2008).

The aim of this study was to investigate the effect of microwave heating on the content of $\mathrm{HCN}$ in linseed samples. As a result of different microwave powers and time of treatment, optimal levels of both parameters were determined, in order to fulfil demand of Serbian regulation on quality of feedstuff.

\section{Materials and Methods}

\section{Linseed Samples}

Samples of linseed cultivated in Vojvodina, Serbia in 2010 were used for the experiments. All treatments were done on linseed from the same producer and same batch. Samples were transported to the laboratory in polypropylene bags, where they were ground on hammer mill (ABC Engineering, Pančevo, Serbia) to pass $1 \mathrm{~mm}$ sieve and stored in dark at room temperature. Moisture content of linseed was 
determined using gravimetrical AOAC Method 950.46 (AOAC 2000), also known as "oven dry" method, and crude ash was done using standard AOAC Method 942.05 (AOAC 2000). For determination of crude protein, Kjeldahl method was used according to AOAC 978.04 Method (AOAC 2000), and crude fibres were determined by AOAC 978.10 Method (AOAC 2000). Soxhlet extraction for determination of total oil content was performed with a Büchi 810 Soxhlet fat extraction apparatus (Soxtec system HT, 1043 Extraction Unit, Foss Tecator $\mathrm{AB}$, Höganäs, Sweden) in accordance with manufacturer procedure and AOCS Method Ba 3-38 (AOCS 2001).

\section{Microwave Treatment}

Microwave oven Gorenje MO-230 DGW (Slovenia) was used for thermal treatment of linseed samples. Each sample was put in a thin layer on glass plate with diameter of 16 $\mathrm{cm}$, uniformly distributed and placed into the microwave oven. Operating frequency of microwave oven was $2450 \mathrm{mHz}$, and working power $240 \mathrm{~W}, 400 \mathrm{~W}, 560 \mathrm{~W}$ and $800 \mathrm{~W}$. Samples were treated for $0,3,6$ and 10 minutes for every working power.

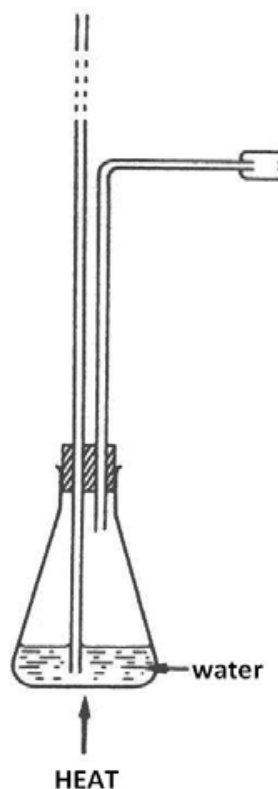

\section{Methods for Chemical Analysis}

Determination of hydrocyanic acid was performed according to AOAC official method 915.03 (part B, alkaline titration method). Hydrolysis of twenty grams (grounded sample) with $200 \mathrm{~mL}$ of water was carried out in a sealed Kjeldehl flask, for 2-4 h. After this the flask was connected to a steam distilling facility. Twenty $\mathrm{mL}$ of $2.5 \%$ sodium hydroxide solution was added to Erlenmeyer flask and the bottom of the cold trap was immersed in it (Fig. 2). $150 \mathrm{~mL}$ of distilled liquid was collected in the the flask. Ammonia and potassium iodide were added to the solution. Silver nitrate standard solution was used for titration, during which its volume was measured and recorded. Equation (1) was used to calculate the HCN content in the sample:

$$
X=C \times V \times 54 \times \frac{\text { dilution }}{\text { aliquot }} \times \frac{1000}{m}
$$

Simbol $X$ stands for the the content of cyanide (including the hydrocyanic acid) in the sample $(\mathrm{mg} / \mathrm{kg}) ; m$ is the mass of the sample $(\mathrm{g}) ; C$ the concentration of silver nitrate standard solution $(\mathrm{mol} / \mathrm{L})$; and $V$ is the volume of silver nitrite standard solution $(\mathrm{mL})$.

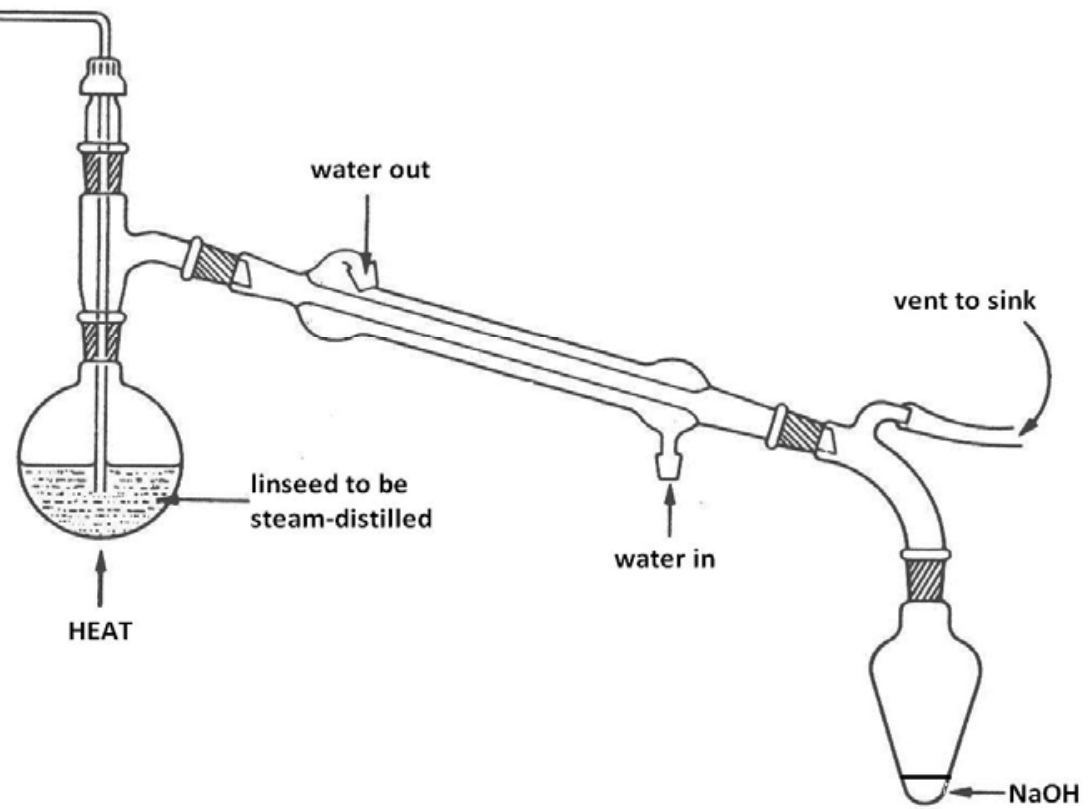

Fig. 2. Apparatus for steam distillation of cyanogenic glycosides Slika 2. Aparatura za destilaciju cijanogenih glikozida vodenom parom 
The removal rate of HCN from linseed was taken as the response, and this can be expressed as equation (2): The removal rate $(\%)$

$$
\begin{gathered}
=\left(1-\frac{\text { the_content_of } \_H C N \_ \text {after_treatment }}{\text { the_content_of }}\right) \times 100 \\
=\left(1-\frac{X}{X o}\right) \times 100 \text { (2) }
\end{gathered}
$$

\section{Statistical analysis}

Statistica software version 9 (Statsoft, Tulsa, OK, USA) was used for analyzing variations (analysis of variance - ANOVA) and for Tukey's HSD comparison of means of samples treated with the microwaves of the same power, but for different time of heating. Differences between mean values with probability $\mathrm{p} \leq 0.05$ were recognized as statistically significant differences, and differences between mean values with 0.05 $\leq \mathrm{p} \leq 0.10$ were recognized as representing tendencies to differences.

\section{Results and Discussion}

All examinations were performed on linseed samples with following chemical composition: moisture content $(6.54 \%)$, crude ash $(2.54 \%)$, crude protein $(22.53 \%)$, crude fibres $(12.02 \%)$, and total oil content (41.28\%).

Obtained results of content of HCN after microwave treatment under different conditions (microwave power and time of heating) are presented in Table 1.

Observing the results, it can be concluded that higher microwave power increased reduction of $\mathrm{HCN}$ content. The same trend could be noticed if linseed samples were heated with microwaves of the same power, but for longer time, as shown in Fig. 3. As already mentioned, Serbian regulation on quality of feedstuff requires maximum of 250 $\mathrm{mg}$ of $\mathrm{HCN} / \mathrm{kg}$ of linseed, which was achieved by treating linseed with microwaves of every examined power, except with $240 \mathrm{~W}$, but for different time of treatment. Microwave power of $400 \mathrm{~W}$ caused increase in $\mathrm{HCN}$ removal rate with time of heating until approximately $450 \mathrm{~s}$, after what there was no change in $\mathrm{HCN}$ removal rate (Fig. 3).

When microwave power of $560 \mathrm{~W}$ and $800 \mathrm{~W}$ for $360 \mathrm{~s}$ and longer was used, linseed samples were burned and damaged, for this reason those seeds could not be used for further analyses. Therefore, it was necessary to find minimum time of heating at $400 \mathrm{~W}$, in order to avoid damaging of linseed samples, and to reduce HCN content under permissible concentration at the same time. For that purpose, dependence of $\mathrm{HCN}$ content with regards to heating time and microwave power was presented trough three-dimensional contour plot graph (Fig. 4), generated by Statistica software, where every contour define specific content of $\mathrm{HCN}$. Minimal time of heating which would provide reduction of $\mathrm{HCN}$ content under $250 \mathrm{mg} / \mathrm{kg}$ of linseed was determined graphically and it was $290 \mathrm{~s}$ ( 4 minutes and $50 \mathrm{~s}$ ). By applying targeted conditions in practice (heating time of $290 \mathrm{~s}$, and microwave power of $400 \mathrm{~W}$ ), achieved removal rate of HCN was $25 \%$, which was in this case, enough to reduce content of $\mathrm{HCN}$ at level of $243 \mathrm{mg} / \mathrm{kg}$ of linseed.

Feng et al. (2003) concluded in their work that microwave roasting achieved the highest level of $\mathrm{HCN}$ reduction in linseed among autoclaving, pelleting and dry-heating in oven. Microwave processing was performed with a microwave oven

Table 1. Content of $\mathrm{HCN} \mathrm{mg} / \mathrm{kg}$ of sample depending on microwave power and time of heating

\begin{tabular}{|c|c|c|c|c|}
\hline \multirow{2}{*}{ Time of heating (s) } & \multicolumn{4}{|c|}{ Microwave power (W) } \\
\hline & 240 & 400 & 560 & 800 \\
\hline 180 & $324 \pm 3.14^{a}$ & $324 \pm 1.28^{\mathrm{a}}$ & $317.25 \pm 2.87^{a}$ & $317.25 \pm 3.14^{\mathrm{a}}$ \\
\hline 360 & $317.25 \pm 2.87^{\mathrm{ab}}$ & $236.25 \pm 2.19^{b}$ & $236.25 \pm 2.19^{\mathrm{b}}$ & $229.50 \pm 2.56^{b}$ \\
\hline
\end{tabular}
Tabela 1. Sadržaj HCN u mg/kg uzorka, u zavisnosti od snage mikrotalasa i dužine vremena zagrevanja

Results are presented as mean $\pm \mathrm{SD}, n=3$

$a-b$, different superscripts within the same column indicate significant differences $(\mathrm{p} \leq 0.05)$ 


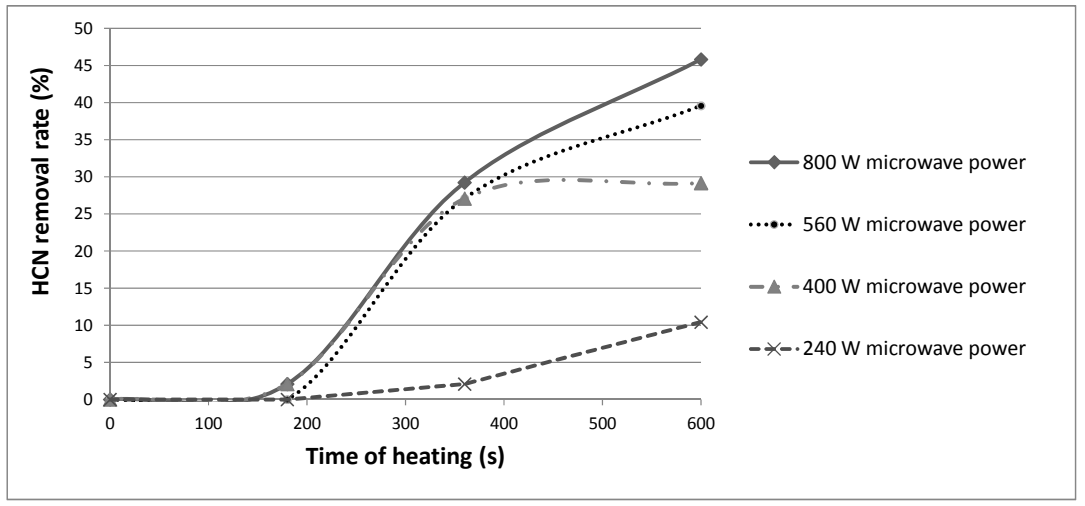

Fig. 3. Influence of heating time on removal rate of $\mathrm{HCN}$ in linseed Slika 3. Uticaj dužine vremena zagevanja na nivo smanjenja $\mathrm{HCN}$ u lanu

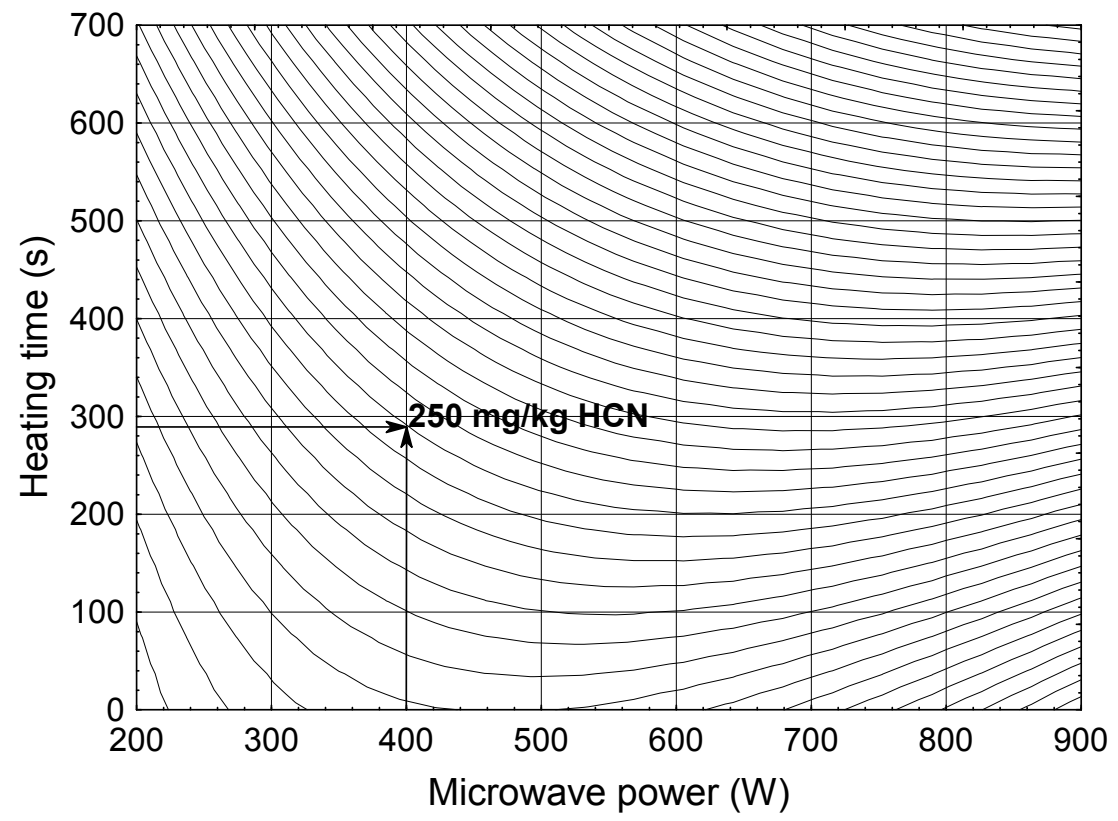

Fig. 4. Determination of optimum microwave power and heating time for reducing $\mathrm{HCN}$ content Slika 4. Određivanje optimalne snage mikrotalasa i vremena zagrevanja za redukciju sadržaja $\mathrm{HCN}$

with $750 \mathrm{~W}$ output, under operating frequency of $2450 \mathrm{MHz}$, for $4 \mathrm{~min}$. They also showed that there were no major changes in the main nutrient and fatty acid profile caused by microwave treatment.

Other authors mentioned toasting as a successful method for destruction of CGs in linseed (Epaminondas et al. 2011). Wu et al. (2008) investigated detoxification of linseed by extrusion. According to their results, extrusion can be considered a highly effective process in removing CGs, but there was no data about comparison between extrusion and other processes.

\section{Conclusion}

In conclusion, the presented study has described relatively simple method for reduction of HCN content in linseed. It was necessary to precisely determine microwaves power used for heating of samples in order to avoid burning of treated material. In the conducted experiment, microwave power of $800 \mathrm{~W}$ and $560 \mathrm{~W}$ damaged the samples. Optimal conditions were defined using three-dimensional contour plot graph. $400 \mathrm{~W}$ of microwave power and $4 \mathrm{~min} 50 \mathrm{~s}$ of treatment were optimal for the reduction of $\mathrm{HCN}$ content under allowed limits. 


\section{References}

AOAC (2000): Official Methods of Analysis, 17th edn. Ed. W. Horwitz, AOAC Int, Arlington, VA, USA

AOCS (2001): Method Ba 3-38, In Official Methods and Recommended Practices, 5 th edn. Ed. D. Firestone, AOCS, Champaign, IL, USA

Bacala R, Barthet V (2007): Development of extraction and gas chromatography analytical methodology for cyanogenic glycosides in flaxseed (Linum usitatissimum). J. AOAC Int. 90: 153-161

Beare-Rogers J, Dieffenbacher A, Holm JV (2001): Lexicon of lipid nutrition (IUPAC Technical report) Pure Appl. Chem. 73: 685-744

Brimer L, Molgaard P (1986): Simple densitometric method for estimation of cyanogenic glycosides and cyanohydrins under field conditions. Biochem. Syst. Ecol. 14: 97-103

Cho AY, Yi KS, Rhim JH, Kim KI, Park JY, Keum EH, Chung J, Oh S (2006): Detection of abnormally high amygdalin content in food by an enzyme immunoassay. Mol. Cells 21: 308-313

European Parliament (2008): Regulation (EC) No 1334/2008 of The European Parliament and of The Council of 16 December 2008 on flavourings and certain food ingredients with flavouring properties for use in and on foods and amending Council Regulation (EEC) No 1601/91, Regulations (EC) No 2232/96 and (EC) No 110/2008 and Directive 2000/13/EC. Official Journal of the European Communities, L354, 34-50

EFSA (2006): Opinion of the scientific panel on contaminants in the food chain on a request from the commission related to cyanogenic compounds as undesirable substances in animal feed question $\mathrm{N}^{\circ}$ EFSA-Q-2003-064.

Feng D, Shen Y, Chavez E (2003): Effectiveness of different processing methods in reducing hydrogen cyanide content of flaxseed. J. Sci. Food Agric. 83: 836-841

Epaminondas PS, Araújo KLGV, Lima de Souza A, Silva MCD, Queiroz N, Souza AL, Soledade LEB, Santos IMG, Souza AG (2011): Influence of toasting on the nutritious and thermal properties of flaxseed. J. Therm. Anal. Calorim. 106: 551-555

Franks TK, Hayasaka Y, Choimes S, Van Heeswijck R (2005): Cyanogenic glucosides in grapevine: polymorphism, identification and developmental pattern. Phytochem. 66: 165-173
Gabiana CP (2005): MSc Thesis, Lincoln University, Canterbury, New Zealand

Ganjewala D, Kumar S, Devi A, Ambika K (2010): Advances in cyanogenic glycosides biosynthesis and analyses in plants: A review. Acta Biologica Szegediensis 54: 1-14

Hidayat A, Zuaraida N, Hanarida I, Damardjati D (2000): Cyanogenic content of cassava root of 179 cultivars grown in Indonesia. J. Food Compost. Anal. 13: 71-82

Juárez M, Dugan MER, Aldai N, Aalhus JL, Patience JF, Zijlstra R, Beaulieu AD (2010): Feeding co-extruded flaxseed to pigs: Effects of duration and feeding level on growth performance and backfat fatty acid composition of grower-finisher pigs. Meat Sci. 84: 578-584

Karlović Đ, Andrić N (1996): Kontrola kvaliteta semena uljarica. Tehnološki fakultet Novi Sad, Savezni zavod za standardizaciju, Beograd

Keusgen, M, Kloock, JP, Knobbe, DT, Junger, M, Krest, I, Goldbach, M, Klein, W, Schoning, MJ (2004): Direct determination of cyanides by potentiometric biosensors. Sens. B. Chem. 103: 380-385

Klosterman HJ (1974): Vitamin B6 antagonist of natural origin. J. Agric. Food Chem. 22: 13-16

Łukaszewicz M, Szopa J, Krasowska A (2004): Susceptibility of lipids from different flax cultivars to peroxidation and its lowering by added antioxidants. Food Chem. 88: 225-231

Madhusudhan KT, Singh N (1985): Effect of detoxification treatment on the physicochemical properties of linseed proteins. J. Agric. Food Chem. 33: 1219-1222

Matheson EM (1976): Linseed. In: EM Matheson (ed.) Vegetable Oil Seed Crops in Australia, Holt, Rinehart and Winston, Sydney (Australia), 111-121

Okanović Đ, Ilić N, Ivanov D, Palić D, Drobnjaković R, Vukčević Č, Ikonić P (2010): Influence of linseed enriched diet on omega-3 fatty acids content in pork. Krmiva 52: 189-194

Republika Srbija (2010): Pravilnik o kvalitetu hrane za životinje, Službeni glasnik Republike Srbije 4: 67

Vetter J (2000): Plant cyanogenic glycosides. Toxicon 38: 11-36

Wu M, Li D, Zhou YG, Brooks MSL, Chen XD, Mao ZH (2008): Extrusion detoxification technique on flaxseed by uniform design optimization. Sep. Purif. Technol. 61: 51-59

\section{Uticaj mikrotalasnog zagrevanja na sadržaj cijanogenih glikozida u semenu lana}

\section{Dušica Ivanov • Bojana Kokić • Tea Brlek • Radmilo Čolović . Đuro Vukmirović · Jovanka Lević · Slavica Sredanović}

Izvod: Lan se smatra odličnim izvorom linolne (LA, 18:2, n-6) a naročito $\alpha$-linolenske kiseline (ALA, 18:3, n-3), $\omega 6$ i $\omega$-3esencijalnih polinezasićenih masnih kiselina. Sisari, pa samim tim i ljudi, nemaju sposobnost da endogeno sintetišu ove masne kiseline, već ih moraju egzogeno usvajati iz hrane. Uprkos pomenutoj visokoj nutritivnoj vrednosti, lan se u ishrani životinja ne eksploatiše efektivno, usled prisustva antinutritivnih komponenata, cijanogenih glikozida (CG) i antivitamina B6 (linatina). CG predstavljaju glavno ograničenje u primeni lana i lanene sačme kao hrane za životinje. Cilj prezentovanog ispitivanja bio je da se istraži uticaj mikrotalasnog zagrevanja na sadržaj cijanovodonične kiseline u lanu, preko koje se određuje i sadržaj cijanogenih glikozida. Operativna frekvencija mikrotalasa bila je $2450 \mathrm{mHz}$, a primenjene su radne snage od 240W, 400W, $560 \mathrm{~W}$ i $800 \mathrm{~W}$. Uzorci su zagrevani 0, 3, 6 i 10 minuta za svaku od navedene radne snage. Upotreba mikrotalasa snage $560 \mathrm{~W}$ i $800 \mathrm{~W}$ u periodu od 6 minuta i duže uzrokovala je oštećenje i spaljivanje uzoraka, pa se stoga ovakav režim zagrevanja ne preporučuje. Minimalno vreme zagrevanja lanenog semena mikrotalasima snage $400 \mathrm{~W}$ koje bi obezbedilo redukciju sadržaja HCN ispod dozvoljene granice propisane Pravilnikom o kvalitetu hrane za životinje 4/2010 (250 mg/kg lanenog semena), određeno je grafički preko trodimenzionalnog konturnog dijagrama i iznosilo je 290 sekundi (4 minuta i 50 sekundi). Ovaj režim se preporučuje za tretiranje lanenog semena pre upotrebe za ishranu životinja.

Ključne reči: cijanogeni glikozidi, lan, mikrotalasno grejanje, cijanovodonična kiselina 